\title{
Contribution of Special Immigrants from among Chechens and Ingush in the Development of the Karaganda Coal Basin in 1944-1957
}

\author{
Zulay Sulimovna Issakiyeva \\ Chechen State University, Grozny, Chechen Republic, Russia
}

Doi:10.5901/mjss.2015.v6n5s3p324

\begin{abstract}
In the presented article, employment of Chechens and Ingush on mines of the Karaganda coal basin in the 40th of the XX century is considered. The Soviet state made successful attempts of socialization of Chechens and Ingush in places of their new accommodation. The deported Chechens and Ingush independently could earn to themselves on livelihood and housing, their standard of living gradually increased. Many families built houses, acquired cattle in private use. The author concludes that sharp needs of the regional economy for labor promoted the further accumulation of scales of utilization in the economy of the area of forced labor, special immigrants from the North Caucasus. Their work was actively used on construction of new mines, coal mining, and mining production, in industrial and civil engineering, and other branches of the economy of Kazakhstan. Work allowed them not only gradually to find a difficult financial position but also was the best option of an exit from a moral and psychological depression. Joint work pulled together the people of the North Caucasus with the local population. Compelled to remain in the foreign land, Chechens and Ingush contributed to the economic development of the Central Kazakhstan. The forced production plans were realized by the price of health and life of miners among which there were Chechens and Ingush.
\end{abstract}

Keywords: special-immigrants, Chechens, Ingush, Karaganda coal basin, mines

\section{Introduction}

The Karaganda coal basin - one of the world's largest. Its development has begun in 1930. It is one of the most important coalfields of the USSR, the third after Donbass and Kuzbass coal base of the country. In the 1940th years to the Karaganda coal basin was in great need of labor. The arrival of Chechens and Ingush, in some degree, has solved a burning issue of shortage of working hands. At the beginning, labor productivity of the special immigrants working at mines and mines was low. The local management explained it with the lack of experience at such enterprises, low labor discipline, and bad living conditions. However, quickly experience and skills of work on mines, mines, and the enterprises came. Many Chechens began to show good operational performance. For August 1944 on «Stalin-coal», trust executed norm there were 586 people and exceeded -543 persons. (State Archives of the Karaganda region. F.18).

It is necessary to refer considerable wear of mine machines and the equipment, lag in coal mining mechanization to the number of the difficulties connected with the transition to peaceful work. It was necessary to expand and preparation of qualified personnel, to raise the level of mining works, to improve the organization of work. It was dictated by new problems of post-war development of the pool. The question of preparation and reception of graduates of schools FT (factory training) and vocational schools was particularly acute.

Technical study on the increase of qualifications among special immigrants - Chechens was carried out due to training at Stakhanov schools, technical schools, mastering of technical school and individually - brigade form of education. Among them, 220 people have passed factory training and have gone to work for production on the professions.

From the first days of the fourth five-year period, the Karaganda miners began to be equipped with new equipment. In 1946in some mines work on passing of vertical shafts have been begun that considerably simplified the operation of old mine fund and facilitated work of miners. Besides, expansion of lines of faces was planned, the quantity of lavas with 168 to 263 increased. (Archive of Karagandaugol combine. P. № 512) "For implementation of the installed program of work - it is specified in the Law on the fourth five-year plan - in every possible way to mechanize labor-intensive processes in the coal industry, in particular to provide broad work on mechanization of loading of coal and loading of breed. According to it to increase park of mechanisms in the coal industry by 3 - 4 times in comparison with pre-war level". (The law on the five-year plan for recovery and development of a national economy of the USSR on 1946-1950)

Post-war years for the Karaganda coal basin were for years not only the proliferation of coal mining but also 
serious high-quality changes of the technology of underground coal mining. These changes were caused by broad implementation of new machines, advanced conveyors, powerful electric locomotives, shunting winches, the beginning of application of metal fastening in clearing and development workings. The mechanized loading of coal on mines of Karaganda has begun in 1945 and made 2,4\% of all underground coal mining. (Archive of Karagandaugol combine. Item 682. 29)

The Karaganda coal basin has nominated outstanding designers. In 1945, the mechanic of mine No. $31 \mathrm{~S}$. S. Makarov on the basis of KPM-1 GTK-3 And cutting machines had created the multiple motor coal combine for powerful layers thanks to which implementation 18 workers were released. In 1948 S. S. Makarov has designed the bulk machine. The chief of the Winner of the State Award mine No. $31 \mathrm{~L}$. V Egorov has designed and has constructed the bulk machine - a coal-bulk plow. This plow was especially effective on low-power layers of bastard coals where the combine gave small productivity. The combine made a compilation of cutting machines and carried out three operations - the sub cabin, breaking ground and loading of coal on the conveyor.

The new equipment in combination with the advanced methods of the organization of work has given the chance substantially to mechanize the most hard, laborious works in mines, to intensify productions, to increase labor productivity of miners. Miners of coal strip mines have achieved considerable progress.

\section{Methods}

Implementation of new powerful excavators, bulldozers, dump plows, boring machines have allowed to mechanize laborintensive processes at open works, to release and transfer hundreds of people to other sites of production, sharply to increase labor productivity.

Fast development of the industry of Karaganda during the post-war period has become possible thanks to dedicated work of special immigrants and creative activity of broad masses, workers of the city.

In 1946 workers of Karaganda have joined in All-Union socialist competitions and have undertaken not only to execute but also to exceed the production program of the first year of a five-years period. Competition has captured $83,3 \%$ of workers of the city. (Socialist Karaganda, 1949)

In People's Commissariat, the enterprises of defense construction where entered Tagillag, Altaylag, Karugol, Kuzbassugol and the industrial defense organizations, was used work of $76060 \mathrm{~h}$. Special immigrants, including teenagers from 14 to 16 years that on an equal basis with all workers of the enterprises also took equal part in enthusiasm for work of people at large. (Archive of Committee on Legal statistics and special accounting of the Prosecutor General's Office of RK, F.16) The Karaganda group of working class from the origin formed as multinational. In its structure, there were Russians, Ukrainians, Kazakhs, Germans, Poles, Tatars, Chechens, Ingush, etc. It has left a mark, both in the process of forming of working class and on the development of consciousness. Communication of different nationalities in the course of production broke, national isolation, promoted establishment of mutual contacts between workers, rallied them to fight for the rights, laid the foundation of international solidarity and friendship of the people.

Thousands of teenagers - special immigrants worked at the industrial enterprises and mines of Kazakhstan, is frequent even children. For work, they were driven by need, difficult financial position. In March 1947 in Kazakhstan 15133 working teenagers aged from 12 till 16 years were. 858 teenagers from among Chechens and Ingush and 329 from among aged people worked at mines of the Karaganda coal basin, Special immigrants in the Karaganda region (2007).

According to the Karaganda regional management of labor reserve for August 20, 1949, among mobilized there was 475 people of undocumented, 140 teens (the teenagers who have not reached full age mean), 181 people of patients. (State Archives of the Karaganda region.F.1P.)

Hunger, household disorder, dissociation of families, death of relatives, a humiliating brand of "the enemy of the people" - all this was necessary to worry to the Chechen teenagers. Only in the fifties, the policy of the state about them changed. July 5, 1954. The Council of Ministers of the USSR adopted the Resolution "About Removal of Some Restrictions in a Legal Status of Special Immigrants". In a change of the existing order, the appearance on registration in bodies of the Ministry of Internal Affairs was established once a year. Children of special immigrants to 16-summer age were struck off the register in bodies of the Ministry of Internal Affairs. (State Archives of the Karaganda region.F.18.)

In the state archive of the Karaganda region, there is a list of the leaders of socialist competition in honor of Day of the miner presented to rewarding with diplomas of the Central Committee of All-Union Leninist Young Communist League for 1950.

Abdurakhmanov Yakhjya - the mine foreman of mine No. 17 of Kalinin of trust Leninugol. The order of the Ministry 
of coal industry USSR№429 - 13.

Sulumanov Hussein- stower plant mines are №6.

Kadyrov Kedar- motor specialist №18.

Tugayev Imran - the chargeman of mine No. 41.

Order Ministry of coal industry USSR Moscow No. 491 - 13 on August 14, 1950, on trust Leninugol. Badge

"Excellent student sots. Competitions Min.Ug.prom. The USSR" Iskakov Ahmed - school.№49.

On trust Molotovugol.

Iskakov Salamgerey - from highway No. 64/83.

Madanov Muhammad - the getter school.№33/34

Shepiyev Abu - from school. №6

Tsitskiyeva Husaina - a traveling section No. 5 on trust Karagandauglerazrez of Art. 45 - the Certificate of appreciation of Ministry of coal industry USSR.

On trust Molotovugol:

Bekmukhamedova Bilal - the drifter school.№64/83

Shamisheva Sharipa - the mine foreman school.№20 - an encore

Sheripov Imran - the mine supervisor school.№50 - 52.

On trust Kirovugol:

Sharipova Damira - sh.№31.

The list of the best people in the enterprises of "Karagandauglerazres" trust represented to rewarding "By a certificate of appreciation Ministry of coal industry USSR ":

Sarbasov Shaykh, 1924 , the member of All-Union Communist Party (bolsheviks) - the foreman of carmen.

Adamov Ales 1930 - from school № 20 encore. - badge "Excellent student sots. Competitions".

Akmaletdinov Shamsuddin - the mine foreman 1927 school.№44/45. 107\% badge "Excellent student sots. Competitions".

Madanov Muhammad - from school №33/34.131\%.

Murzamanov Hozhakhmed 1901 - from school.№42/43. 254\%

Shepiyev Abu - from school.№6.104\%

Kankayev Muhammad 1915- from school.№6.117,9\%

Tsitskiyev Husain - a traveling section No. 5 on trust "Karagandauglerazrez" of 136\%

Kamiyev Murat 1929- from school.№33/34 126\%. (State Archives of the Karaganda region.A.341.).

In post-war years, training of skilled workers for the industry and transport had important value. The state labor reserves were one of the forms of replenishment of working class - in this system the broad preparation of qualified personnel for the leading industries, transport and construction was carried out. Mobilization of youth in FT (factory training) schools, vocational and railway schools was conducted as well as mobilization to labor army, based on government documents. In FT (factory training) schools, the youth was called (a male at the age of 15-17 years and a female at the age of 16-18 years). (Central State Archive of the Republic of Kazakhstan, F.1109).

One of the main defining factors of development of the third coal USSR base was its continuous replenishment by the trained skilled workers and engineering and technical personnel workers. Schools and schools in six years - from 1951 to 1956 have prepared and have transferred to the enterprises of Karagandaugol combine a significant amount of machine operator's personnel from among Chechens and Ingush. Training of skilled workers directly on mines and plants of the Karaganda coal basin it was carried out in two directions: professional development of employees and training of new personnel. Carrying out historical solutions XX of Congress, and June 1955 of the plenum of the Central Committee of CPSU the Karagandaugol combine in 1956 has achieved improvement of training of skilled workers of personnel. In essence, it was the new grade level of miners. (Party archive of the Karaganda regional committee of the F.172op.2)

Most of Chechens and Ingush have passed technical training; have left seven-year school, secondary school. 50 The 60th years of last century the Karaganda mines are well known for the implementation of new mountain equipment, the advanced form of the organization of work and the whole hail of world records on coal mining. "You give the world!" the hottest slogan of that time.

These years the new movement has widely extended certain workers assumed obligations for early implementation of the annual personal plans. The foundation of this movement has been laid by a youth site of mine No. 55 - 57 where Grigory Stepanov was the supervising supervisor.

This initiative has been picked up by young workers of other mines and buildings of the coal basin and became an important form of the fight of masses for the early performance of a five-year period. Getters of mine No. 42/43 Dudarov Anas and Makhayev Makhdi have achieved the daily performance standard for $130 \%$. 
In 1950 a breastplate "The excellent student of socialist competition" is awarded by the Ministry of the coal industry of the USSR the foreman of a way of the Mikhaylovsky uglerazrez No. 5 Tsitskiyev Husen Aslambekovich 1930 executed norms for 1950: January - 132\%, February - 135\%, March - 136\%, April - 185\%, May - 112\%; in only 5 months 136\%. (Karaganda State Archive of the Russian Federation .F.341).

In 1949, the tunneling crew of Dudarov Anas had established an all-Union record on passing. It is the result of the growth of a technological level and creative initiative.

From 1945 to 1958 Dudarov Anas has passed a big labor way. It worked as the getter, the supervisor, the mine supervisor; the assistant to the supervising foreman, from 1955 to 1958 has worked the supervising foreman No. 2. Directing the leading site in difficult mining-and-geological conditions of comrade Dudarov Anas always exceeded the State plan. Proceeding from it the Socialist Karaganda newspaper of August 13 1955goda wrote:

The fourth site of Stalin regional council Ali Saralapov, the worker of a place of loading of coal in railway cars Avkhad Madayev and many other miners enjoys significant authority on mine No. 42/43.

Anas Dudarov even had ten years ago no idea how coal is extracted. He and now remembers how the first time has gone down in mine. Frightening it seemed underground.

- It is unlikely I will master this business - the thought tormented it.

Doubts were vain. Anas Dudarov not only has well studied all mining processes of steep dipping formation but became the commander of the production - the supervising foreman. The second site, which is directed by comrade Dudarov, is one of the front lines on mine. He has organized the development of a lower coat of above average layer, according to the schedule of recurrence. Dredging of coal from steep dipping formation - business hard. Also, comrade Dudarov directs all attention on that in a lava the set operating mode that the defects, which are found when maintaining benching system of production of fuel, were under way eliminated was observed. As a result, following the results of work for July the site has won superiority in competition. He has successfully coped with the standard of recurrence and in a month has given out on - the mountain more than 1.000 tons of coal in excess of the plan. In the first decade of August a lava, it was daily scraped. Best of all the integrated team to Bill Ayubova works at this site. On the watch in honor of the XX Congress and Day of the miner crew of comrade. Ayubova daily performs production target for $120 \%$, gives out on the mountain ten tons of coal in excess of the plan. In response to solutions of Plenum of CPSU, the collective of a site run by comrade Dudarov has undertaken to implement the annual plan of coal mining by Day of the Soviet Constitution. (Socialist Karaganda.13 of August 1955).

Among the staff of mine of t. Dudarov Anas enjoyed big authority, was elected the deputy in the regional council of workers. Was accepted by primary party organization in ranks of members of CPSU from members of All-Union Leninist Young Communist League. Among Chechens and Ingush Anas Mumadovich was one of the advanced propagandists on carrying out party - economic actions. As it is noted in records of the service record, for outstanding merits before the state and staff of mine of comrade Dudarov Anas has repeatedly been marked out by diplomas, monetary and ware values.

August 24, 1951. "For the reached high operational performance in socialist competition by day of the Miner" the Certificate of Honor awards comrade Dudarov.

"The committee of a labor union, the party organization and administration of mine No. 42/43 award the Certificate of honor of Comrade Dudarov Anas, as the best worker who has caused a stir in socialist competition in 1953."

August 24, 1954. "For the reached high operational performance in socialist competition by day of the Miner of comrade Dudarov Anas is awarded the Certificate of Honor.

April 27, 1956. "For achievement of high operational performance on a site in premay

Socialist competition is supervising foreman No. 2 of mine No. 42/43 companion Dudarov Anas is awarded by the certificate of honor.

On November 19, 1957 "the Central Committee of All-Union Leninist Young Communist League awards the present diploma of Dudarov Anas - the supervising foreman of mine No. 42/43, for the high operational performance reached in socialist competition in honor of the 40th anniversary of the Great October Socialist revolution".

From the protocol of the Joint meeting of Stalin RKSU and trust Stalinugol of July 10, 1955:

Provide to Karagandaugol combine and the Karaganda regional committee of a labor union on the award of red banners, as satisfied conditions on All-Union socialist competition: The first place a site No. 2 of mine No. $42 / 43$ - the supervising foreman of t. Dudarov Anas, chairman of Professional Committee of t. Tasukhanov, who has implemented the plan of coal mining for $120.8 \%$, the standard of recurrence for $110.4 \%$, labor productivity for $125.5 \%$ at the average performance of norms for 130\%. (PMA 2009-Field material of the author)

On January 9, 1957, the Decree of the Supreme Council of the USSR (State Archive of the Russian Federation.F.7523) and Presidium of the Supreme Council of RSFSR (Repressed people of Russia: Chechens and 
Ingush, 1994) about the recovery of an autonomy of ChIASSR has been issued. Thereof, the Department of Internal Affairs of the Karaganda committee has issued the certificate to Dudarov Anas that he is the chief of the Echelon followed from the Karaganda region who is granted the right of registration, payments of railway administration of the expenses connected with sending people, also maintenance of an echelon to terminal station of assignment.

Anas Dudarov was the irreplaceable supervising foreman on "Chechenskaya" mine No. 42/43. In this regard, on October 10,1962, the party organization of Karagandaugol combine addresses to the District Committee of Party of the Nadterechny region of ChIASSR: The party organization and mine - management of mine No. $42 / 43$ of Stalinugol trust of Karagandaugol combine asks the District Committee of Party of the Nadterechny region of Chl Autonomous Soviet Socialist Republic to release for work of the coal industry of comrade Dudarov Anas who is earlier working as the supervising foreman. We ask not to refuse to our request. Chief of mine 42/43: Cormorants. Secretary of a Communist Party organization of mine 42/43: Starichenko (PMA-2009. Field materials of the author).

Among the deported Chechens and Ingushs, there were many leaders of the coal industry. The man of an award of Labor glory of three degrees Imran Gazimiyev worked in Kazakhuglerazvedka trust together with 124 Chechens. Then Imran was transferred to the advanced "Chechen" mine No. 42/43 which gave every year in excess of the plan thousands of tons of coal. Indicators of work of mine No. 20 encore for 1950.

Ismailov Salavda - the driller of a site No. 1 of mine No. 20 - 118\% (State Archives of the Karaganda region.F.341). Advanced working crews, participants. Makhmedov Uvays - the drifter of mine No. 20 - 135.8\%, (State Archives of the Karaganda region.F.341). Kadyrov A. - the brusher of mine No. 20 - 154\%, (State Archives of the Karaganda region.F.341)

As, the rule, heads of mines left ranks of the same miners. Otherwise, they could never find a single language with them. Such head who does not know mine, people, it is ignored, and no attempts of administrative character would force to respect the head and this main thing in the performance of objectives. And the mine foreman Makhayev Makhadi, the supervising foreman Dudarov Anas, Murtazov Ahmed, Kokurkhoyev Ahmed, Tsurov Mahomed, Vasikhanov Lecha, Akhmadov Abdulkhalak, Satuyev Sapar, Ependiyev Rizvan, Durkayev Usman, Durkayev Shuta, Adalkhanov Alavdi, Kubayev Abubakar, Kavrayev Ismail, Sambulatov Khalid, Reshedov Shapagi, Hamzayev Oumar and many other Chechens and Ingush were such heads.

From the documentary publication: This history had happened in those days when miners extracted coal underground without any mechanics. Only two forces - horse and human were used. Mines lowered deep into horses on ropes where they dragged heavy trolleys until died. Poor animals have been doomed to live in outer darkness where instead of the sun there was the light of dim lamps and abuse of miners. They could not already be lifted upward - horses instantly grew blind from the bright light. In one of such mines in the middle of the XX century Chechen Sayd-Salakh, as the fates decree, who has appeared in Kazakhstan among foreign people and customs worked. His father was dear smith-armorer by the name of Mokhayd, and mother - the homemaker who is bringing up ten children. A family, as well as hundreds of other families, have sent under Stalin's decree from Chechnya in snow February 1944. Many their native and friends were lost. The non-transportable - old men, children and patients (their deportation was represented to the most difficult for employees of People's Commissariat for Internal Affairs) - have been driven in a big shed stable of the aul of Haybakh and alive burned. Those who tried to escape - were shot. About one thousand people have been so destroyed. The survived families in the foreign land had not to choose work. Work in mine was difficult, dangerous, man. Sayd-Salakh to support a family slaved away. The chief even spoke: "Be not you the Chechen - would give you an award Hera of Socialist Work." However, the nationality - "has brought". The photo Sayd-Salakha has received a constant registration on an honor wall where marked out the most worthy toilers, the working some changes in a row. On a wall of Honors or to a wall - the choice at it was small.

Once at the end of change there was an accident: methane explosion. The collapse began. People, saving the lives, started hiding in a niche of tunnels, special apertures where was available though some protection against a hail of stones. The scared horses neighed, rattled, rushed about. Sayd-Salakh rushed to a saving niche but was not in time - a stream of the earth, sand, and small stones immured it: miracle was on a surface only ahead. He did not feel either hands nor feet, could not even move them. Rescued that it fell between cross ties - they covered it from the blow. With the last bit of strength, Sayd-Salakh threw back the head and looked at mines up - in hope to see a light gleam, but saw a stone. The huge cobblestone with an improbable speed flied down, directly on it! "Bismillah Rahmani Rahim" - started reading hasty words of a prayer of Sayd-Salakh, assuming that this last that he will get on well with life. Pressed a chin to a breast, expecting blow. The stone fell in some millimeters from it nearby. In a day, rescuers reached Sayd-Salakha (Word and stone, http://wordyou.ru/kolonki/slovo-i-kamen)

Participating in the implementation of post-war five-year plans, Chechens and Ingush achieved not only the best operational performance but mastered new qualifications. For example, on Stalinugol trust the best Stakhanovites - 
Chechens have been nominated to senior positions: Mutushev Nazhmurda, Kachuyev Vakh are transferred from drifters by foremen, Magomadov, Khasbulatov and Hamzayev are appointed from the shift foreman by supervising foremen. Mine supervisors Zhumalayev, Masayev, Dzhabarov, Makhayev, Mezhidov working as drillers became shift foremen.

Thus, work of Chechens and Ingush in the system of Karagandaugol combine - a striking example of their participation in the implementation of production plans of the Soviet five-year periods. In the beginning, labor productivity of the special immigrants working at mines and mines was low. The local management explained it with the lack of experience at such enterprises, low labor discipline, and bad living conditions. However, gradually experience and skills of work on mines, the businesses and mines came. Many of them the honest work have achieved recognition not only in the collective but also beyond its limits. Some Chechens became example samples about which infrequently but mentioned in the press. Government awards have marked some of them out. The leaders of the area noted the presence of Stakhanovites and drummers from among Chechens and Ingush at the enterprises of the Karaganda coal basin.

From the list of the leaders of socialist competition, in honor of Day of the miner provided to rewarding with diplomas of the Central Committee of All-Union Leninist Young Communist League:

Abdurakhmanov Yakhjya - the mine supervisor of coalpit №17 of Kalinin of trust Leninugol. Order of the Ministry of the coal industry of the USSR No. 429-13 Moscow, 8 August 1953.

Suleymanov Husain - the brusher of workshop of mine No. 6

Kadyrov Kedar - a motor specialist of mine No. 6

Tugayev Imran - the chargeman of mine No. 41

The order of the Ministry of the coal industry of the USSR No. 491-14-13 Moscow, on August 14, 1950 on trust Leninugol the Excellent Student of Socialist Competition of the Ministry of the Coal Industry of the USSR Badge of Iskakov Ahmed - the getter of mine No. 49,

On trust Iskakov Selim's Molotovugol - from mine No. 64/83

Madenov Muhammad - the getter of mine No. 33/34

Shatimov Abu - the getter of mine No. 6

On trust Karagandauglerazrez of Art. 45

Tsitskiyeva Husaina - a traveling section No. 5

Certificate of appreciation of the Ministry of the coal industry of the USSR of trust Molotovugol

Bekmukhamedova Belasha - the drifter of mine No. 64/83

Shamisheva Sharipa - the mine foreman of mine No. 20 - an encore

Sheripova Alikhamida - the mine foreman of mine No. 50/52

on trust Kirovugol

Sharipov Tagir - the getter of mine No. 31

The list of the best people in the enterprises of Karagandauglerazrez trust represented to rewarding with "A certificate of appreciation of the Ministry of the coal industry of the USSR"

Sarbasov Shaykh, 1924, a member of All-Union Communist Party (bolsheviks) foreman of Carmen.

The list of the workers represented to rewarding with a badge "The excellent student of socialist competition of municipal unitary enterprise" in Stalinugol trust of Karagandaugol combine

Adamov Elie, 1930 - the mine foreman of mine No. 20 - 124\%

Akhmetdinov Shamsutdin, 1927 - the mine foreman ш.№44/45 - 147\%

Madenov Muhammad, 1920 the non-party - the getter of mine No. 33/34 - 131\%

The list of workers, ITR and the serving mines and enterprises of Kirovugol trust provided to rewarding with the Sign "Excellent Student of Socialist Competition."

Murzamanov Hozhakhmed 1901 an indicator of the executed norm of 1950 of 254\% in 5 months a medal. "For valorous work in the Second World War in 1941-1945".

Shaytilov Abu 1905 the getter "For labor difference" 104\%

Kankayev Muhammad 1915 getter medal "For Labour Valour", medal. "For valorous work in the Second World War in 1941-1945" 117,9\%

Tsitskiyev Abdoul 1911 the getter "For labor valor" 126\%

Kamiyev Murat 1929 "For valorous work in the Second World War in 1941-1945 y." 128\%. (State Archives of the Karaganda region.F.633).

\section{Results and Discussions}

The biography of each of them is a biography of the worker of the country in which dedicated work is the highest merit of 
the person before the people. They the work laid the foundation of the industrial power of the Soviet state, were initiators of the all-Union movement for the early performance of tasks of the first five-years periods. Chechens and Ingush were irreplaceable workers on mines. They have mastered a set of adjacent professions. Among them were: blasters, the foreman, brushers, getters, surveyors who have brought the work not one medal and ranks of the Hero of Socialist Work to figureheads.

Certainly, occupation by work, work in spheres of production gave the chance to special immigrants to correct the situation, to come nearer at least to the minimum opportunities of satisfaction of the requirements. Participation of Chechens and Ingush in public life together with other special immigrants promoted the improvement of their situation in society, change in their relation to life, forming of national consciousness.

\section{References}

State Archives of the Karaganda region. F.18. Op.1. D.843.L.96.

Archive of Karagandaugol combine. P. № 512. D.11.L.39.

The law on the five-year plan for recovery and development of a national economy of the USSR on 1946-1950. M. pp. 8.

Archive of Karagandaugol combine. Item 682. 29.

Socialist Karaganda (1949). Daulbayev N. Karagandinsky coal basin. pp. 287.

Archive of Committee on Legal statistics and special accounting of the Prosecutor General's Office of RK, F.16, Op.1, 13.

Special immigrants in the Karaganda region (2007): Saturday. doc. Moreover, materials. HAG.

State Archives of the Karaganda region.F.1P. Op.7. D.133.L.7-13.

State Archives of the Karaganda region.F.18. Op.6. D.75.L.24-26.

State Archives of the Karaganda region.A.341.Op.20.D.270.272.267.L.25-26.L.173.L 4-6.

Central State Archive of the Republic of Kazakhstan, F.1109, Op.2, 28.

Party archive of the Karaganda regional committee of the F.172op.2 party. D.51.L.47.

Karaganda State Archive of the Russian Federation .F.341. Op.20. D.15.L81.

Socialist Karaganda.13 of August 1955.

PMA 2009-Field material of the author. Personal archive of Dudarov Anas. S. Verkhny. Naur ChR.

State Archive of the Russian Federation.F.7523. Op.72. D.701.L.72.

Repressed people of Russia: Chechens and Ingush (1994). Sost. F. Bugay. M. pp. 206-207.

PMA-2009. Field materials of the author. Personal archive of Dudarov Anas of the page. Upper - Naur

State Archives of the Karaganda region.F.341. Op.20. D.269.L .405

State Archives of the Karaganda region.F.341. Op.20. D.269.L. 536

State Archives of the Karaganda region.F.341. Op.20. D.269.L. 538

http://wordyou.ru/kolonki/slovo-i-kamen. Radikal.Ru life Price. Word and stone. Polina Zherebtsova, writer-documentary filmmaker.

State Archives of the Karaganda region.F.633 of Op.1. 252-. L. 536 